\title{
JAKUB BARSZCZEWSKI
}

UNIWERSYTET W BIAŁYMSTOKU

E-MAIL: KUBABARSZCZEWSKI@WP.PL

\section{TWORZENIE BOLIWIJSKIEGO PAŃSTWA WIELONARODOWEGO A OPÓR WOBEC NEOLIBERALNEJ GLOBALIZACJI}

W 1989 roku Międzynarodowa Organizacja Pracy przyjęła Konwencję nr 169 w sprawie ludności rdzennej i plemiennej. Potwierdzała ona prawo ludności tubylczej do tworzenia i rozwijania własnych instytucji, prawną ochronę ich kulturalnych, religijnych i duchowych wartości oraz praktyk. Z kolei w roku 2006 ONZ ogłosiła Deklarację Praw Ludów Tubylczych, która ponownie potwierdzała ich podstawowe prawa. Zapewniała ludności tubylczej możliwość samookreślania się, zakazywała ich przymusowej asymilacji przez państwo oraz zmuszania do opuszczania zamieszkałych terenów i określała prawo do rozwoju własnych instytucji kulturalnych i nauczania języka. Boliwia była pierwszym państwem, które włączyło te zapisy do własnego systemu prawnego, uznając prawa ludności rdzennej. Decyzja zatwierdzona została przez wywodzącego się z ludności tubylczej prezydenta Evo Moralesa. Była elementem szerszego programu upodmiotowienia ludności rdzennej przez budowę państwa wielonarodowego. Celem było stworzenie państwa, które zapewni równouprawnienie dyskryminowanej dotąd ludności oraz w większym stopniu włączy ją do życia społecznego i politycznego kraju. W dalszej perspektywie zamierzano zmienić model państwa, który miał być oparty na zrównoważonym rozwoju, bardziej egalitarnej organizacji społeczeństwa oraz maksymalnym ograniczeniu obowiązywania logiki rynkowej w różnych dziedzinach życia. Zmiana ta miała uwzględniać doświadczenia, dziedzictwo kulturowe oraz wartości, wokół których ludność tubylcza organizowała swoje życie społeczne. Wzięcie pod uwagę radykalnie odmiennego modelu organizacji gospodarki i życia społecznego oraz próba wcielenia go w życie wymierzone było w dotychczasowy model państwa, dostosowujący się do wymogów neoliberalnej glo- 
balizacji (urynkowienie kolejnych sfer życia, ograniczenie polityki socjalnej państwa, nacisk na potrzebę rozwoju gospodarczego kosztem obniżenia jakości życia).

Niejednorodność boliwijskiego społeczeństwa wynika z kolonialnej przeszłości tego kraju: 66 \% mieszkańców uznaje się za Indian, 25\% uważa się za Metysów, potomków ludności europejskiej i tubylczej, a 10\% stanowi ludność kreolska, wywodząca się bezpośrednio od europejskich osadników. Jako najmniej liczna grupa jest najlepiej usytuowaną ekonomicznie ludnością i dotychczas miała najsilniejszą pozycję polityczną w kraju. Ludność tubylcza, poza wykluczeniem ekonomicznym, stanowi obiekt rasistowskiej przemocy ze strony grup dominujących - Kreolów i Metysów [Farthing, Kohl 2014: 22].

Źródła obecnej dyskusji wokół modelu państwa oraz problemu wielonarodowości sięgają okresu lat dziewięćdziesiątych XX wieku. Uchwalenie w 1994 roku prawa o ludowej partycypacji (Ley de Participación Popular) wprowadziło decentralizację kraju oraz przekazanie lokalnym gminom środków z budżetu centralnego. Odtąd 20\% krajowego budżetu miało być rozdzielane między 311 nowo powstałych gmin. Małe miasta i wiejskie wspólnoty po raz pierwszy uzyskały możliwość wyboru lokalnych rządów [Farthing, Kohl 2014: 22].

Proces decentralizacji przyczynił się do wzmocnienia tożsamości ludności tubylczej. Doprowadził do zwiększenia politycznej partycypacji ludności na terenach wiejskich, które zazwyczaj pomijane były przez partie polityczne. Reformy administracyjne nie zdołały jednak rozwiązać najbardziej palących problemów: zmniejszenia ubóstwa oraz pełnego upodmiotowienia ludności tubylczej. Jednak nadanie minimalnych praw politycznych ludności rdzennej poszerzyło ich możliwości uczestnictwa w życiu politycznym kraju, co znalazło swój oddźwięk w wydarzeniach, jakie miały miejsce kilka lat później [Kohl 2006: 96-100].

Kolejnym bardzo istotnym wydarzeniem $\mathrm{w}$ procesie upodmiotowienia ludności tubylczej były konflikty społeczne w pierwszej dekadzie XXI wieku. Ludność tubylcza, będąc najbardziej wykluczoną ekonomicznie grupą w społeczeństwie boliwijskim, odegrała bardzo ważną rolę w powstrzymaniu prywatyzacji przedsiębiorstwa wodnego w Cochabamba w roku 2000 (tak zwana wojna o wodę). W latach 2003 i 2005 w znacznym stopniu przyczyniła się również do obalenia dwóch prezydentów, którzy prowadzili politykę uderzającą w ich interesy [Farthing, Kohl 2014: 8].

Jednym z najważniejszych uczestników tych wydarzeń, a następnie przekształcenia Boliwii w państwo wielonarodowe, był Ruch na rzecz So- 
cjalizmu (Movimiento al Socialismo-Instrumento Político por la Soberanía de los Pueblos). Powstał on pod koniec lat dziewięćdziesiątych, gdy indiańscy chłopi i hodowcy koki dostrzegli ograniczenia wynikające z działalności w skali lokalnej oraz potrzebę rozszerzenia swojej działalności na poziom ogólnokrajowy. Specyfika tej organizacji polega na tym, że funkcjonuje ona raczej jako konglomerat oddolnych ruchów ludności indiańskiej, a nie typowa partia polityczna ze sztywnym kierownictwem i organizacją władzy. W swoich postulatach odwołują się oni zarówno do marksizmu, jak i tradycji ludności indiańskiej. Szczególnie widoczne było to w wystąpieniach skierowanych przeciwko neoliberalnej polityce poprzednich rządów, w których ideę walki o emancypację indiańskiej tożsamości wiązano z ideą walki klasowej [Webber 2011: 128-130].

Ramy teoretyczne do opisu powstania boliwijskiego państwa wielonarodowego dostarczyć może Boaventura de Sousa Santos, portugalski socjolog zaangażowany w proces jego tworzenia. Postrzega on próby wdrożenia takiego modelu państwa jako jeden z czynników sprzyjający kontrhegemonicznej globalizacji, tak zwanego oddolnego procesu globalizacji, w którym przezwyciężone zostaną relacje dominacji ekonomicznej, kulturowej i politycznej, obecne w modelu globalizacji neoliberalnej. Koncepcja kontrhegemonicznej globalizacji zwraca uwagę na to, że prawomocność danego modelu globalizacji wynika $\mathrm{z}$ instytucjonalnego uprawomocnienia i naturalizacji określonej wiedzy, koncepcji i przekonań. Dlatego walka z obecnym modelem globalizacji musi rozpocząć się od przezwyciężenia prawomocności pojęć i koncepcji stojących u jego podstaw oraz zaproponowanie alternatywnych rozwiązań. Do tej kwestii odnosi się jedno z kluczowych pojęć Santosa - epistemologie Południa.

„Mówiąc o epistemologiach Południa mam na myśli wyszukiwanie nowych procesów wytwarzania i oceny wartości prawomocnej wiedzy, czy to naukowej, czy nie, oraz nowych stosunków między różnymi typami wiedzy na podstawie praktyk klas i grup społecznych, które systematycznie cierpiały ucisk i dyskryminację spowodowaną przez kapitalizm i kolonializm. (...) Epistemologie Południa składają się z dwóch następujących założeń. Po pierwsze, dostrzeżenie, że sposób, w jaki można postrzegać świat jest znacznie szerszy od sposobu, w jaki postrzega go Zachód. Oznacza to, że postępowa zmiana świata może również nastąpić na sposób, który nie został przewidziany przez zachodnie myślenie, także zachodnią myśl krytyczną (nie wyłączając marksizmu). Po drugie, różnorodność świata jest nieskończona. To właśnie różnorodność zawiera w sobie zasadniczo odmienne sposoby życia, myślenia, odczuwania, sposobów postrzegania czasu i relacji między 
ludźmi oraz relacji między ludźmi a nie-ludźmi, sposobów stawiania czoła przeszłości i przyszłości oraz zbiorowej organizacji życia, produkcji dóbr i usług, jak i czasu wolnego. Ten bezmiar alternatywnych sposobów życia, współżycia oraz interakcji ze światem w znacznym stopniu ulega marnotrawstwu, ponieważ teorie i pojęcia rozwinięte na globalnej Północy oraz używane w całym świecie akademickim nie dostrzegają takich alternatywnych możliwości” [Santos 2012: 51].

Santos, będąc krytykiem zachodniego modelu nowoczesnego państwa (które nie jest w stanie poradzić sobie ze złożonością problemów i procesów rozgrywających się we współczesnych społeczeństwach w Ameryce Południowej), proponuje inny model państwa. Jego zdaniem, współczesne walki o emancypację indiańskiej tożsamości w Boliwii są przejawem tak zwanego transformacyjnego konstytucjonalizmu, będącego alternatywą wobec upowszechnionego na Zachodzie nowoczesnego konstytucjonalizmu. Ten ostatni charakterystyczny jest dla homogenicznych pod względem narodowym społeczeństw odwołujących się do jednej kultury, systemu edukacji i prawa. Taki model państwa narzucony został koloniom. Tak więc utrzymywanie go nie pozwala zerwać z dziedzictwem kolonializmu, stojącym na drodze do emancypacji społeczeństw zamieszkujących byłe kolonie. Z kolei transformacyjny konstytucjonalizm opiera swój model państwa na oddolnych, formułowanych przez grupy wykluczone dążeniach, na przykład do tworzenia nowych instytucji, uzyskiwania nowych praw i wprowadzania nowych zasad administracyjnych, które pozwolą im zapewnić większą podmiotowość i rozwiązać ignorowane dotąd problemy. To na jego podstawie formułowana jest koncepcja państwa wielonarodowego, która ma na celu konstytucyjne potwierdzenie wielokulturowości, wieloetniczności i wielonarodowości państwa oraz przyznanie praw ludności tubylczej, zajmującej dotąd podrzędną pozycję w społeczeństwie [Santos 2007: 20-22]. Rozpatrując to w szerszej perspektywie, konstytucyjne potwierdzenie praw ludności tubylczej do odmienności sprzyja przezwyciężeniu pozostałości po epoce kolonialnej, stawiającej ich w podrzędnej pozycji.Zkolei polityczne upodmiotowienie może przyczynić się do umocnienia ich pozycji politycznej w kraju oraz przekształcenia ich $\mathrm{w}$ lepiej zorganizowany podmiot sprzeciwiający się hegemonicznemu modelowi globalizacji.

Wysuwane przez ludność rdzenną żądania stworzenia państwa wielonarodowego wynikają $\mathrm{z}$ niezadowolenia $\mathrm{z}$ dotychczasowych modeli państwa. W przeszłości model liberalny, rozwojowy czy biurokratyczny był jedynie przedłużeniem kolonialnej dominacji Zachodu i nie pozwalał 
na pełną emancypację grup dyskryminowanych (między innymi ludności tubylczej, rolników), narzucając określony model rozwoju i życia [Santos 2010: 69-70].

„Koncepcja wielonarodowości jest żądaniem uznania odmiennego pojęcia narodu, narodu rozumianego jako wspólna przynależność do grupy etnicznej, kultury czy religii. Mówiąc językiem praw człowieka, koncepcja wielonarodowości wiąże się z uznaniem praw zbiorowych grup społecznych w sytuacjach, w których prawa jednostkowe tworzących je osób okazują się nieskuteczne w zapewnieniu uznania i trwałości ich tożsamości kulturowej czy położenia kresu społecznej dyskryminacji, której padają ofiarą" [Santos 2010: 81].

Boaventura de Sousa Santos zwraca uwagę na to, że współczesne dyskusje w Ameryce Południowej wokół roli, jaką ma odgrywać państwo w życiu społecznym (czego przejawem są dążenia do budowy państwa wielonarodowego), wiążą się z trzema postulatami: odrynkowienia, demokratyzacji i dekolonizacji. Wynikają one z nieadekwatności obecnego modelu zachodniego państwa nowoczesnego ze względu na jego niezdolność do rozwiązania istniejących problemów grup wykluczonych. Punktem wyjścia tych postulatów są epistemologie Południa, kładące nacisk na to, że lokalna wiedza, wytworzone na Południu i organizujące życie społeczne mieszkającej tam ludności, jest równie prawomocna, co wiedza wytworzona na Zachodzie. Po pierwsze, odrynkowienie opiera się na przekonaniu, że należy przezwyciężyć naturalizację kapitalizmu jako jedynej formy organizacji życia społecznego. W tym celu konieczne wydaje się wyłączenie określonych obszarów życia społecznego spoza logiki rynkowej oraz prawa własności prywatnej, zastępując go innymi formami gospodarowania oraz własności (wspólnotowej, publicznej, spółdzielczej). Poza tym należy wprowadzić konkretne rozwiązania w gospodarce: na przykład ekonomię społeczną, wspólnotową, kontrolę publiczną strategicznych zasobów, od których zależy jakość życia ludności obywateli. Po drugie, demokratyzacja dąży do przezwyciężenia specyficznego pojęcia demokracji, które zazwyczaj ograniczane jest do rozpowszechnionego w świecie zachodnim modelu demokracji przedstawicielskiej. Dlatego ma na celu uzupełnienie tego modelu innymi formami demokratycznej deliberacji oraz szukanie powiązań między nimi (na przykład modelem przedstawicielskim, uczestniczącym i wspólnotowym). Dzięki uprawomocnieniu innych form demokratycznej kontroli możliwe będzie rozszerzenie zasady demokratyczności na inne sfery życia (na przykład relacje rodzinne, relacje w tradycyjnych wspólnotach, prawomocność określonej wiedzy w organizowaniu życia społeczne- 
go) i zaprzestanie redukowania jej wyłącznie do przestrzegania formalnych procedur instytucji demokratycznego państwa. Po trzecie, dekolonizacja ma służyć przezwyciężeniu rasizmu oraz demaskować techniki i instytucje, które je reprodukują. Dotyczy to zarówno instytucjonalnie zakorzenionych praktyk (na przykład edukacja), jak i utrwalania rasowej niższości w życiu codziennym (na przykład wyrażającego się w potocznym rozsądku czy stereotypach) [Santos 2010: 130-131].

Koncepcja państwa wielonarodowego jest zmianą paradygmatu roli, jaką odgrywać ma państwo. Dotychczas różne rejony kraju były pozbawione zainteresowania ze strony instytucji państwowych. Wyprowadzenie z podrzędnej pozycji zamieszkującej tam ludności rdzennej nie było możliwe ze względu na brak propozycji systemowych rozwiązań. Obszary te, będąc terenem ekspansji ponadnarodowych korporacji, mogły liczyć jedynie na punktowe rozwiązania wysuwane przez organizacje pozarządowe. Aktywna polityka państwa wynika z założenia, że nie jest możliwe rzeczywiste upodmiotowienie ludności (umożliwienie pełnego uczestnictwa w życiu publicznym) bez konsekwentnej polityki, która wyposaży ich w podstawowe możliwości rozwoju (na przykład edukacja), [Ramírez 2010: 152].

Krokiem do ugruntowania państwa wielonarodowego było uchwalenie w roku 2009 nowej konstytucji. Przyznawała ona rdzennym grupom status odrębnych narodów. Zatwierdzała ich równouprawnienie oraz uznawała ich prawo do odrębności oraz własnego modelu życia. Przyznała im szeroką autonomię oraz ustanawiała korzystną dla nich pozytywną dyskryminację w wyborach do parlamentu. W ten sposób konstytucja ostatecznie znosiła historyczną marginalizację ludności tubylczej i funkcjonowanie jej w roli obywateli drugiej kategorii.

W zapisach konstytucyjnych bardzo wyraźnie zostało zaznaczone uznanie dziedzictwa kulturowego Indian za dziedzictwo narodowe Boliwii. Rdzenna tradycja i obyczajowość zrównana została z wartościami nowoczesnych społeczeństw, dowodząc, że nie ma między nimi sprzeczności:

Artykuł 8.

„I. Państwo uznaje i sprzyja wartościom etyczno-moralnym pluralistycznego społeczeństwa: ama qhilla, ama llulla, ama suwa (nie bądź gnuśnym, nie bądź kłamcą, nie bądź złodziejem), suma qamaña (dobre życie) [vivir bien], ñandereko (harmonijne życie), teko kavi (pomyślne życie), ivi maraei (ziemia wolna od zła) i qhapaj ñan (szlachetna droga lub życie). 
II. Państwo opiera się na wartościach jedności, równości, inkluzji, godności, wolności, solidarności, wzajemności, szacunku, komplementarności, harmonii, przejrzystości, równowagi, równości szans, równości społecznej i płciowej w partycypacji, dobra wspólnego, odpowiedzialności, sprawiedliwości społecznej, dystrybucji i redystrybucji produktów i dóbr społecznych służących dobremu życiu” [Constitución 2010: 12].

Konstytucja nie ogranicza uznania dziedzictwa kulturowego ludności tubylczej wyłącznie do tradycji i obyczajowości. Ochronę i poparcie ze strony państwa otrzymały również tradycyjne formy organizacji gospodarki, będące podstawą organizacji życia społecznego rdzennych wspólnot:

Artykuł 306.

„I. Model gospodarczy Boliwii ma charakter pluralistyczny i ukierunkowany jest na poprawę jakości życia i dobrego życia wszystkich mieszkańców i mieszkanek Boliwii.

II. Pluralistyczna gospodarka składa się z wspólnotowej, państwowej, prywatnej i spółdzielczej formy organizacji gospodarki.

III. Pluralistyczna gospodarka wiąże ze sobą różne formy organizacji gospodarki na zasadach komplementarności, wzajemności, solidarności, redystrybucji, równości, pewności prawa, zrównoważonego rozwoju, równowagi, sprawiedliwości i przejrzystości. Społeczna i wspólnotowa gospodarka poprzez dobre życie (vivir bien) zbiorowości stanowić będzie dopełnienie interesu jednostki. (...)

Artykuł 307.

Państwo będzie uznawać, szanować, chronić i sprzyjać wspólnotowej organizacji gospodarki. Ta forma organizacji gospodarki obejmuje systemy produkcji i reprodukcji życia społecznego, opartych na zasadach i wizji właściwych dla narodów i rodzimych ludów tubylczych" [Constitución 2010: 121].

Zasada wielonarodowości państwa determinuje wprowadzenie samorządności, mającej zapewnić autonomię różnym grupom narodowościowym. Z kolei realizacja koncepcji samorządności wymaga stworzenia nowego rodzaju instytucji państwowych, nowej organizacji terytorialnej, demokracji międzykulturowej, pluralizmu prawnego, nowego typu polityki publicznej (np. w kwestii ochrony zdrowia, edukacji, systemu za- 
bezpieczeń społecznych), nowych kryteriów obywatelskiej partycypacji [Santos 2010: 81].

Instytucje państwa wielonarodowego mają przede wszystkim służyć poszanowaniu odmienności różnych grup narodowościowych, służyć ich równemu traktowaniu i reprezentacji. Wprowadzenie w życie zasady samorządności wymaga również nowego podziału terytorialnego, w którym uwzględnione zostaną tereny autonomiczne różnych grup narodowościowych [Santos 2010: 84-87].

Zapewnienie rzeczywistej autonomii musi wiązać się z wprowadzeniem pluralizmu prawnego, który znosi upowszechnioną w większości państw zasadę, że to państwo jest wyłącznym źródłem jednolitego prawa. Zgodnie z założeniami pluralizmu prawnego, grupy narodowościowe mają możliwość posiadania własnego systemu prawnego oraz sprawowania wynikających z niego funkcji (między innymi sądownictwo). Mogą organizować życie społeczne wokół własnego prawa oraz we własnym zakresie rozwiązywać lokalne konflikty, pod warunkiem, że działanie poszczególnych systemów różnych grup zostanie uzgodnione $\mathrm{z}$ ogólnym systemem prawnym państwa [Santos i in. 2012: 16-20].

Równouprawnienie tradycji i obyczajowości różnych grup narodowościowych w jednym państwie wymaga rozpatrywania zasady i procedur demokratycznych w perspektywie wielokulturowości. Międzykulturowa demokracja zakłada konieczność współistnienia różnych form demokratycznej deliberacji (na przykład podejmowania decyzji w indywidualnym głosowaniu, poprzez konsensus, sprawowanie funkcji w wyniku wyborów, rotacji stanowisk, zasady obligatoryjnego sprawowania danej funkcji). Wiąże się również z różnymi kryteriami reprezentacji (charakterystycznych dla świata zachodniego kryteriów ilościowych oraz typowych dla ludności tubylczej kryteriów jakościowych). Zwraca uwagę na to, że uznanie praw zbiorowych ludów jest warunkiem działania praw jednostkowych oraz kładzie nacisk na potrzebę uznanie nowych praw podstawowych: między innymi prawa do wody, ziemi, suwerenności żywieniowej, zasobów naturalnych [Santos 2010: 98].

W konstytucji wielokrotnie pojawia się określenie potrzeby zapewnienia dobrego życia (bien vivir), które odnosi się do tradycji ludów indiańskich - organizacji życia opartej na zrównoważonym rozwoju, likwidacji ubóstwa, bardziej sprawiedliwym podziale dóbr oraz zasadzie solidarności. Model ten, mimo że odwołuje się do języka przednowoczesnego, w ogólnym zarysie jest zbieżny z postulatami ruchów alterglobalistycznych. Zarówno alterglobaliści z Północy, jak i ruchy indiańskie z Południa opowiadają się 
za zaprzestaniem traktowania większości dóbr i usług oraz przyrody w kategoriach towaru oraz sprzeciwiają się uzależnianiu sposobu rozwoju kraju i życia ludności od procesów globalizacyjnych, będących w interesie rozwiniętych gospodarczo krajów Północy. Konstytucyjne wprowadzenie zasady buen vivir nie tylko zauważa potrzebę ochrony ludności pierwotnej przed polityką, będącą następstwem procesów globalizacji (na przykład prywatyzacji zamieszkałych przez nią terenów), ale również sprzyja poszukiwaniu form sprzeciwu wobec obecnego modelu globalizacji.

Stworzenie państwa wielonarodowego pozwoliło poprawić pozycję Indian $\mathrm{w}$ boliwijskim społeczeństwie. O sukcesie świadczy pomyślne włączenie ich w życie polityczne oraz zwiększenie ich reprezentacji w organach ustawodawczych. O ile za pierwszej kadencji Evo Moralesa w Wielonarodowym Zgromadzeniu Ustawodawczym 17\% deputowanych wywodziło się z ludności tubylczej, o tyle w kolejnej kadencji stanowili oni już 25\% wszystkich deputowanych. Żadnemu innemu krajowi Ameryki Południowej nie udało się osiągnąć tak dobrego wyniku w politycznym upodmiotowieniu rdzennej ludności. W roku 2010, realizując program walki z rasizmem, którego ludność tubylcza często pada ofiarą, wprowadzono antydyskryminacyjne i antyrasistowskie prawo penalizujące rozpowszechnianie poglądów o charakterze rasistowskim [Farthing, Kohl 2014: 65].

Dokonano również zmian w systemie edukacji. Uwzględniając oczekiwania ludności tubylczej, wprowadzono Indiańskie Rady Oświatowe, które miały stworzyć nowe prawo oparte na konsultacjach z lokalnymi wspólnotami. Aby ugruntować równouprawnienie dziedzictwa kulturowego ludności indiańskiej, wprowadzono obowiązkową naukę języka i kultury indiańskiej obok nauki języka hiszpańskiego i wiedzy o kulturze zachodniej. Zmiany dotyczyły również edukacji wyższej. W 2008 roku stworzono trzy indiańskie uniwersytety, które miały kształcić studentów wywodzących się z ludności tubylczej, zapewniając im jednocześnie środki finansowe na utrzymanie [Farthing, Kohl 2014: 106-107].

W 2010 roku weszło w życie Prawo o autonomii i decentralizacji, które wprowadzało autonomię w gminach i na terytoriach indiańskich. Było to symboliczne dokończenie nieudanej neoliberalnej reformy samorządowej z połowy lat dziewięćdziesiątych, usiłującej wprowadzić model państwa wielonarodowego [Farthing, Kohl 2014: 124].

Pojawiają się również bardzo pesymistyczne głosy kwestionujące możliwość przeprowadzenia w Boliwii szybkiej emancypacji ludności indiańskiej oraz budowy egalitarnego społeczeństwa wielokulturowego. Jeffery 
R. Webber wskazuje, że za rządów Evo Moralesa, uważanego za reprezentanta interesów Indian, dochodziło do bardzo poważnych konfliktów z rdzenną ludnością. W 2010 roku wybuchł konflikt z Konfederacją Ludów Indiańskich Boliwii, będący rezultatem niezadowolenia $\mathrm{z}$ realizacji zapisów konstytucyjnych. Rozczarowani przedstawiciele ludności tubylczej wyrazili wówczas swój sprzeciw w antyrządowych marszach protestacyjnych. Przyczyną kolejnego poważnego konfliktu z ludnością tubylczą była niezgoda na plany budowy drogi, która przebiegała przez tereny należące do ludności tubylczej. W 2011 roku decyzja budowy drogi na terenie Parku Narodowego Territorio Indígena y Parque Nacional Isiboro-Secure wzbudziło ogromny sprzeciw zamieszkałej tam ludności. Doszło wówczas do poważnych starć między rządem a Indianami. Decyzja o budowie drogi łamała uchwalone wcześniej prawo do samorządności i samostanowienia. Inny zarzut wskazujący na porażkę projektu wielonarodowego państwa i realizacji egalitarnego modelu buen vivir odwołuje się do niespełnienia obietnicy nacjonalizacji strategicznych przedsiębiorstw, które wciąż pozostają w rękach ponadnarodowych korporacji. Mimo zapowiedzi budowy gospodarki promującej upowszechnienie egalitarnych i zrównoważonych form życia społecznego, własności i gospodarowania, w wielu dziedzinach życia wciąż jest realizowany, a nawet umacniany, neoliberalny model gospodarki. Takiej polityce towarzyszy uelastycznianie praw do autonomii terytoriów indiańskich oraz regulacji dotyczących ochrony środowiska. Najbardziej poważnym zarzutem wobec realizowanego przez obecny rząd projektu wielokulturowego państwa jest podejrzenie o koniunkturalizm. Jeffery R. Webber uważa, że część ludności tubylczej, która uzyskała silną pozycję w kluczowych gałęziach gospodarki (na przykład górnictwie) dobrze odnajduje się w obecnym modelu gospodarki i nie chce głębszych zmian. Dlatego liczący się z ich pozycją rząd, wcale nie dąży do wprowadzania nowego bardziej egalitarnego modelu społeczeństwa i gospodarki. Korzystając z pomyślnej sytuacji ekonomicznej, koncentruje się na maksymalizacji wzrostu gospodarczego, marginalizując organizacje indiańskie, które przeciwstawiają się takiej polityce [Webber 2015].

Mimo że wcielenie w życie projektu państwa wielonarodowego w Boliwii budzi duże kontrowersje i nie spełniło wszystkich oczekiwań, to, nie można mówić o jego całkowitej porażce. Idea wielonarodowego państwa wynikała z oddolnych żądań dyskryminowanej ekonomicznie i rasowo grupy, zrodziła aktywność na rzecz zmiany krzywdzących regulacji i ostatecznie 
doprowadziła (przynajmniej do pewnego stopnia) do realizacji oczekiwanych rozwiązań. W procesie tworzenia państwa wielonarodowego udało się upodmiotowić wykluczone dotąd grupy, włączyć ich do życia politycznego oraz wyposażyć w podstawowe środki do życia przez politykę redystrybucyjną. Towarzyszyło temu konstytucyjne dowartościowanie indiańskiego dziedzictwa kulturowego oraz próba realizacji wynikających z tego dziedzictwa postulatów dotyczących modelu gospodarki i życia społecznego. Stworzenie państwa wielonarodowego odegrało również pozytywną rolę z punktu widzenia koncepcji kontrhegemonicznej globalizacji. Pozwoliło zachować własną tożsamość i autonomię grupom, które opierają się obecnemu modelowi globalizacji. Uprawomocniło wiedzę, do jakiej odwołują się one $\mathrm{w}$ swoim sprzeciwie wobec globalizacji oraz pozwoliło na dalsze wypracowywanie na podstawie tej wiedzy nowych form oporu. Mimo niespełnienia oczekiwań radykalnej zmiany modelu gospodarczego państwa, doprowadziło do wyegzekwowania korzystnych rozwiązań w ramach tego modelu. Umocniło $\mathrm{w}$ ten sposób pozycję grup będących największymi ofiarami globalizacji i dało im podstawy do przyszłych zmagań o jej inny kształt.

\section{Bibliografia}

Constitución política del Estado plurinacional de Bolivia, (2010), La Paz.

Farthing L. C., Kohl B. H. (2014), Evo's Bolivia. Continuity and change.

Kohl B. H. (2006), Impasse in Bolivia. Neoliberal hegemony and popular resistence, London.

Ramírez R. (2010), Los nuevos retos de América Latina. Socialismo y Sumak Kawsay, Quito.

Santos B. de Sousa (2007), La reinvención del estado y el estado plurinacional. Cochabamba.

Santos B. de Sousa (2010), Refundación del Estado en América Latina. Perspectivas desde una epistemología del sur, Buenos Aires.

Santos B. de Sousa (2012), Public Sphere and Epistemologies of the South, "Africa Development", t. XXXVII, nr 1, 43-67.

Santos B. de Sousa i in. (2012), Justicia indígena, plurinacionalidad e interculturalidad en Bolivia, Quito.

Webber J. R. (2011), Red October. Left-indigenous struggles in modern Bolivia, Leiden. 


\section{Dokumenty elektroniczne}

Webber J. R. (2014), Bolivia's Passive Revolution. „Jacobin”: https://www.jacobinmag.co$\mathrm{m} / 2015 / 10 /$ morales-bolivia-chavez-castro-mas, [13.12.2015].

\section{SUMmaRY}

\section{Making of Plurinational State of Bolivia and resistance to neoliberal globalization}

The article focuses on the relation between indigenous social movements' struggle for establishment of plurinational state and resistance to neoliberal globalization. It present origins of movements for indigenous empowerment, reforms which provided indigenous people with new rights and shows effects of these reforms. Author proves usefulness of the concept of counter-hegemonic globalization proposed by Boaventura de Sousa Santos in evaluation of these processes. Describes also characteristics of plurinational state and its role in the process of democratization, decommodification and decolonization of Bolivian society. Finally, analyzes current positive and negative consequences of establishment in Bolivia plurinational model of state and indicates new possibilities of struggle with neoliberal globalization.

KEYWORDS: globalization, Bolivia, emancipation, social movements, Boaventura de Sousa Santos 